\title{
Effect of Cilembu Sweet Potato Starch and Storage Times on Physicochemical and Microbiology of Synbiotic Yoghurt Ice Cream
}

\author{
Lestari Kusumah Dewi ${ }^{1^{*}}$, Lilik Eka Radiati ${ }^{2}$, Imam Thohari ${ }^{2}$ \\ ${ }^{1}$ Master Program of Animal Products Technology, Faculty of Animal Husbandry, University of Brawijaya, Malang, \\ Indonesia \\ ${ }^{2}$ Department of Animal Products Technology, Faculty of Animal Husbandry, University of Brawijaya, Malang, Indonesia
}

\begin{abstract}
The purpose of this research was to determine the effect of adding cilembu sweet potato starch (1-6 \%) and storage time $(2,4,6$ weeks) on physicochemical and microbiology of synbiotic yoghurt ice cream. The research methodology used was experiment laboratory. The first experiment was designed by Completely Randomized Design (CRD) using 7 treatments and 4 replications, while second step was designed by CRD using 4 treatments and 4 replications. Data were analized by Analysis of Variance (ANOVA) and continued by Duncan's Multiple Range Test (DMRT). Determination of the best treatment used Effectiveness Index, which has been modified. The result of first step showed the best treatment is the addition of cilembu sweet potato starch $3 \%$ with value $5.400 \log 10 \mathrm{cfu} . \mathrm{mL}^{-1}$ of total LAB, 4.322 of pH, $0.200 \mathrm{~g} . \mathrm{L}^{-1}$ of EPS, $40.257 \mathrm{P}$ of viscosity, 35.523 minutes. $50 \mathrm{~g}^{-1}$ of melting rate, $30.258 \%$ of overrun. For second step, the best treatment is 6 weeks stored with value $5.004 \log 10 \mathrm{cfu} . \mathrm{mL}^{-1}$ of total LAB, 4.347 of pH, $0.327 \mathrm{~g} . \mathrm{L}^{-1}$ of EPS, $114.928 \mathrm{P}$ of viscosity, 48.828 minutes. $50 \mathrm{~g}^{-1}$ of melting rate.
\end{abstract}

Keywords: cilembu sweet potato,exopolysaccharides, ice cream, periods

\section{INTRODUCTION}

Yoghurt is produced from fermented milk with the addition of starter. Yoghurt starter consist of Lactic Acid Bacteria (LAB), may include Lactobacillus bulgaricus, Streptococcus thermophilus [1] and Lactobacillus acidophilus. During the fermentation process, LAB will hydrolyze lactose into its constituent compounds, glucose and galactose [2]. Metabolism of sugars will produce energy and organic acids, such as lactic acid, citric acid and others. The acid formation will cause a decrease in $\mathrm{pH}$ [3]. Addition of cilembu sweet potato starch can increase total $L A B$. The increase in total $L A B$ will cause a decrease of $\mathrm{pH}$ due to a growing number of lactose-hydrolyzed LAB become acidic. The growth of pathogenic bacteria is inhibited due to the acids formed.

Yoghurt can be processed into yoghurt ice cream that can be modified by the addition of cilembu sweet potato starch as a prebiotic, which is known as the synbiotic yoghurt ice cream. Synbiotic ice cream is a product that should be stored in freezing conditions, while the viability of $L A B$ will be decreased when stored at freezing temperatures. Thus, it should be added with

\footnotetext{
${ }^{*}$ Correspondence author:

Lestari Kusumah Dewi

Email : kusumah.lestari@yahoo.co.id

Address : Faculty of Animal Husbandry, University of Brawijaya, Jl. Veteran Malang, 65145
}

cryoprotectant to minimize the loss of viability of LAB. One of the cryoprotectant that can be used is cilembu sweet potato starch.

Cilembu sweet potato starch contains oligosaccharides which were not digestable to the human intestine [4]. Cilembu sweet potato starch has high oligosaccharides at $\pm 0.272 \%$, while purple sweet potato at $\pm 0.126 \%$ and white sweet potato at $\pm 0.099 \%$ [5]. Sweet potato's oligosaccharides as a prebiotic potential, so it could support the growth of Lactobacillus [6]. Streptococcus thermophilus started the fermentation process by breaks down the lactose into glucose and galactose. Lactobacillus bulgaricus will change monosaccharide into lactic acid. Lactic acid bacteria are capable of producing exopolysaccharide (EPS).

Exopolysaccharide is a polysaccharide that excreted by bacteria, fungi, or algae and found on the outside of the cell wall. Exopolysaccharide composed of two polymers, heteropolysaccharide and homopolysaccharide. Heteropolysaccharide is a polysaccharide composed by several types of monosaccharides. Homopolysaccharideis a polysaccharide composed of a single type of monosaccharides [7]. Exopolysaccharide of $L A B$ is heteropolysaccharides with straight and branched chain repeating units of tetra-heptasaccharides [8].

Starch composed of amylopectin molecules have a high water absorption capability [9], thus 
it can increase the viscosity of the synbiotic yogurt ice cream. Synbiotic yogurt ice cream will have a low melting rate when the viscosity was high. Branching chains of amylopectin molecules related through $\alpha-1.6$ group that really solid [10], so its lead to decrease of overrun due to current processing and freezing in the ice cream production, the air is hard to get into the ice cream mixed (ICM).

Based on this, it is necessary to make a research about the addition of cilembu sweet potato starch $1-6 \%\left({\left.\mathrm{v} . \mathrm{w}^{-1}\right)}^{-1}\right.$ and 2-6 weeks frozen storage $\left(-18^{\circ} \mathrm{C}\right)$. Previous research suggests that the addition of cilembu starch as much as $1-3 \%$, with a concentration of $3 \%$ gave the best results against the total of LAB. Thus, further assumption that the addition of $3 \%$ is a maximum point for bacterial growth, thus it is necessary to increase the concentration of cilembu starch. The addition of cilembu starch limited to $6 \%$ related to the texture of synbiotic ice cream. The maximum value of total solids in ice cream is $42 \%$. Storage for 2-6 weeks conducted to determine the quality of synbiotic ice cream, whether $L A B$ is able to survive after being kept frozen for up to 6 weeks, and determine the decrease of LAB. Every stage of the research tested a total LAB, pH, EPS production, microstructure, viscosity, melting rate and overrun.

\section{MATERIALS AND METHODS}

The materials consisted of yogurt (fresh cow's milk was derived from the Mitra Bhakti Makmur Cooperative, Junrejo-Malang. Starter derived from the House of Yoghurt Junrejo-Malang. Other ingredients are cilembu sweet potato starch (sweet potato from Karangploso, Batu), sugar, full cream milk powder (Dancow brands), and emulsifiers (Quick brands).

\section{Starch Isolation Procedures}

Sweet potatoes was peeled, shredded, and then mixed with water (ratio $1 \mathrm{~kg}: 1$ liter). Then filtered with deposited for 8-12 hours. The water was separated from the starch sediment. The wet starch dried under the sunlight, then mashed with spoon.

The method used was laboratory experiment with completely randomized design (CRD), 7 treatments and 4 replications with the addition of starch $\mathrm{P}_{1}(1 \%), \mathrm{P}_{2}(2 \%), \mathrm{P}_{3}(3 \%), \mathrm{P}_{4}(4 \%), \mathrm{P}_{5}$ (5\%), $P_{6}$ (6\%). Frozen storage time used 4 treatments, i.e. $T_{0}, T_{1}$ (2 weeks), $T_{2}$ (4 weeks), and $\mathrm{T}_{3}$ (6 weeks) in 4 replications.

\section{Data Analysis}

The observed variables were total $L A B, p H$, EPS, microstructure using Scanning Electron Microscopy (SEM), viscosity, melting rate and overrun. Data were analyzed using ANOVA and Duncan's Multiple Range Test. The qualitative data were analyzed descriptively. Determination of the best treatment used Effectiveness Index [11] which has been modified.

\section{RESULT AND DISCUSSION}

The quality of synbiotic yoghurt ice cream in terms of physicochemical properties and microbiology can be seen in the Table 1 and 2 .

\section{Total LAB}

ANOVA showed that the addition of cilembu sweet potato starch with different concentration on synbiotic yoghurt ice cream provide highly significant difference $(P \leq 0.01)$ of the total $L A B$. The addition of cilembu sweet potato starch $3 \%$ produced highest value of total $L A B$, i.e. $5.400 \mathrm{log}$ $10 \mathrm{cfu} \cdot \mathrm{mL}^{-1}$. Enhancement of total LAB occurs on the addition of cilembu sweet potato starch 1$3 \%$. The addition of cilembu sweet potato starch $4-6 \%$ decreased the total LAB. The addition of cilembu sweet potato starch $6 \%$ produced the lowest total LAB, i.e. $5.291 \log 10 \mathrm{cfu} \cdot \mathrm{mL}^{-1}$. The addition of $6 \%$ starch inhibit the activity of $L A B$ compared to the addition of starch $3 \%$ with the same number of additional starter $\left(3 \% . L^{-1}\right.$ of milk). It indicates that $L A B$ is less capable of hydrolyzing starch because starch concentration was higher than $L A B$, causing $L A B$ urgency and decreased activity, conversely to the addition of $3 \%$ cilembu starch.

Increasing total LAB happened because the addition of cilembu sweet potato starch in yoghurt fermentation that used by $L A B$ to support their activities and growth. Cilembu sweet potato starch have a high oligosaccharides [5]. Oligosaccharides is not digestable by human because the absence of $\alpha$-galactosidase enzyme. Thus intestinal bacteria ferment it and produce gas, e.g. $\mathrm{H}_{2}$ and $\mathrm{CO}_{2}$ [6], therefore oligosaccharides used better as a prebiotic for LAB. Previous studies mentioned that fermented yoghurt enriched with sweet potato produce fast growth speed of $L A B$ and doubling total LAB for $0.5880 . \mathrm{h}^{-}$ ${ }^{1}$ and 6.0985 times (10\% orange sweet potato), $0.5589 . \mathrm{h}^{-1}$ and 5.6837 times (10\% purple sweet potato), $0.4510 . \mathrm{h}^{-1}$ and 5.5671 times (10\% white sweet potato) [12]. From the results of these studies, this research is fairly good because we used orange sweet potato starch as a prebiotic. 
Table 1. The Quality of Synbiotic Yoghurt Ice Cream with Addition of Cilembu Sweet Potato Starch

\begin{tabular}{|c|c|c|c|c|c|c|}
\hline \multirow[b]{2}{*}{ Treatments } & \multicolumn{6}{|c|}{ Average } \\
\hline & $\begin{array}{c}\text { Total LAB (log } 10 \\
\left.\text { cfu.mL } \mathrm{mL}^{-1}\right)\end{array}$ & pH & $\operatorname{EPS}\left(\mathrm{g} \cdot \mathrm{L}^{-1}\right)$ & Viscosity (P) & $\begin{array}{c}\text { Melting Rate } \\
\left(\text { minutes.50g }{ }^{-1}\right)\end{array}$ & Overrun (\%) \\
\hline $\mathrm{P}_{0}$ & $5.052 \pm 0.011^{\mathrm{a}}$ & $4.616 \pm 0.268^{b}$ & $0.124 \pm 0.002^{a}$ & $10.621 \pm 0.306^{\mathrm{a}}$ & $26.150 \pm 0.984^{a}$ & $89.865 \pm 0.414^{\mathrm{g}}$ \\
\hline$P_{1}$ & $5.149 \pm 0.011^{b}$ & $4.410 \pm 0.081^{\mathrm{a}}$ & $0.127 \pm 0.003^{\mathrm{a}}$ & $20.049 \pm 0.432^{b}$ & $27.793 \pm 1.252^{\mathrm{a}}$ & $87.311 \pm 0.455^{f}$ \\
\hline $\mathrm{P}_{2}$ & $5.286 \pm 0.025^{c}$ & $4.364 \pm 0.044^{\mathrm{a}}$ & $0.128 \pm 0.007^{\mathrm{a}}$ & $34.286 \pm 0.587^{c}$ & $30.185 \pm 2.252^{b}$ & $66.278 \pm 0.238^{\mathrm{e}}$ \\
\hline$P_{3}$ & $5.400 \pm 0.004^{\mathrm{e}}$ & $4.322 \pm 0.002^{\mathrm{a}}$ & $0.200 \pm 0.072^{b}$ & $40.257 \pm 0.296^{d}$ & $35.523 \pm 0.754^{c}$ & $30.258 \pm 1.208^{d}$ \\
\hline $\mathrm{P}_{4}$ & $5.363 \pm 0.003^{d}$ & $4.344 \pm 0.003^{\mathrm{a}}$ & $0.174 \pm 0.026^{\mathrm{ab}}$ & $56.220 \pm 0.218^{\mathrm{e}}$ & $37.913 \pm 0.635^{d}$ & $23.079 \pm 0.317^{c}$ \\
\hline$P_{5}$ & $5.312 \pm 0.023^{c}$ & $4.352 \pm 0.003^{a}$ & $0.146 \pm 0.003^{a}$ & $87.670 \pm 0.715^{f}$ & $41.365 \pm 0.845^{e}$ & $15.122 \pm 0.346^{b}$ \\
\hline $\mathrm{P}_{6}$ & $5.291 \pm 0.010^{c}$ & $4.360 \pm 0.002^{\mathrm{a}}$ & $0.133 \pm 0.005^{\mathrm{a}}$ & $103.180 \pm 0.872^{\mathrm{g}}$ & $45.050 \pm 0.337^{f}$ & $10.257 \pm 0.305^{a}$ \\
\hline
\end{tabular}

Description: different superscripts showed a highly significant difference $(P \leq 0.01)$

Table 2. The Quality of Synbiotic Yogurt Ice Cream with Frozen Storages

\begin{tabular}{|c|c|c|c|c|c|}
\hline \multirow[b]{2}{*}{ Treatments } & \multicolumn{5}{|c|}{ Average } \\
\hline & $\begin{array}{c}\text { Total LAB (log } 10 \\
\left.\text { cfu.mL } L^{-1}\right)\end{array}$ & $\mathrm{pH}$ & $\operatorname{EPS}\left(g \cdot L^{-1}\right)$ & Viscosity (P) & 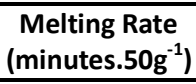 \\
\hline $\mathrm{T}_{0}$ & $5.400 \pm 0.004^{d}$ & $4.322 \pm 0.002^{\mathrm{a}}$ & $0.200 \pm 0.072^{\mathrm{a}}$ & $40.257 \pm 0.269^{a}$ & $35.523 \pm 0.754^{a}$ \\
\hline $\mathrm{T}_{1}$ & $5.303 \pm 0.006^{c}$ & $4.329 \pm 0.027^{\mathrm{a}}$ & $0.205 \pm 0.025^{\mathrm{a}}$ & $59.072 \pm 10.089^{b}$ & $36.990 \pm 2.086^{\mathrm{a}}$ \\
\hline $\mathrm{T}_{2}$ & $5.179 \pm 0.007^{b}$ & $4.344 \pm 0.034^{\mathrm{a}}$ & $0.250 \pm 0.041^{\mathrm{ab}}$ & $89.718 \pm 0.178^{c}$ & $40.925 \pm 1.142^{b}$ \\
\hline $\mathrm{T}_{3}$ & $5.004 \pm 0.011^{\mathrm{a}}$ & $4.347 \pm 0.032^{\mathrm{a}}$ & $0.327 \pm 0.021^{b}$ & $114.928 \pm 0.394^{d}$ & $48.828 \pm 0.915^{c}$ \\
\hline
\end{tabular}

Description: different superscripts showed a highly significant difference $(\mathrm{P} \leq 0.01)$

Analysis of variance showed that different frozen storage times on synbiotic yoghurt ice cream provide highly significant difference $(P \leq 0.01)$ of the total $L A B$. Growth of $L A B$ will be slower under the temperature of $10^{\circ} \mathrm{C}$ [13]. The higher difference temperature of storage and optimum temperature growth of bacterial, will further slowing the growth of $L A B$, ultimately there is no growth anymore [14]. The longer storage time in freezing temperatures, the lower of ability of $L A B$ to live, thus the quality of the synbiotic ice cream will decline in terms of the presence of $L A B$; whereas the fermentation product should contain sufficient LAB that are beneficial for health.

One study suggested that the ice cream with the addition of Lactobacillus bulgaricus and Streptococcus thermophillus had average viability of LAB for $22.1 \times 10^{8}$ cells. $\mathrm{mL}^{-1}$. After being frozen stored for one month, the average viability of LAB decreased into $6.15 \times 10^{8}$ cells. $\mathrm{mL}^{-1}$ [14]. Ice cream contained Lactobacillus acidophilus stored for 5 weeks at a temperature of $-29^{\circ} \mathrm{C}$, decreased viability of LAB from $1.0 \times 10^{8}$ cfu. $\mathrm{mL}^{-1}$ to $4 \times 10^{6}$ cfu. $\mathrm{mL}^{-1}[15]$. That study showed that the storage time of ice cream at freezing temperatures can reduce the viability of $L A B$, because the longer $L A B$ live in freezing temperatures which is not an optimum temperature for LAB growth.
Cause of bacteria death due to low temperatures was cell damage. Cell damage arises from changes in osmotic pressure. Crystallization of water will trigger the solution becomes viscous, thereby causing osmotic damage [13]. Crystalline form of taper and large crystal size can cause bacterial death.The formation of ice crystals can destroy bacterial cell walls, thus cell death can occur. The longer storage, the more ice crystal formed so many bacterial cells are damaged and lower the viability.

Cells undergoing frozen storage process requires a cryoprotectant to prevent cell damage. Cryoprotectant materials used in the research is a Cilembu sweet potato starch, its use will reduce adverse effects. During the frozen storage decreased in osmotic and the formation of ice crystals will occur around the medium but not inside the cell. Cryoprotectant can be divided into two, penetration and nonpenetration[16]. Sweet potato starch can be categorized as non penetration cryoprotectant because it is not able to penetrate into the cells, but only protects the inside of the bacterial cell membrane, thus stabilizing the membrane against freezing damage. The freezing process can reduce up to 1 log cycle of bacteria [17], but from the results obtained in total LAB does not decline until it reaches $1 \mathrm{log}$, this indicates that the starch is able to carry out their duties as cryoprotectant. 
$\mathrm{pH}$

The results of ANOVA showed that the addition of Cilembu sweet potato starch with different concentration on synbiotic yoghurt ice cream provide significant difference $(P \leq 0.05)$ of the $\mathrm{pH}$ values. The addition of starch $3 \%$ produced lowest $\mathrm{pH}$ value, i.e. 4.322. Changes in $\mathrm{pH}$ value were influenced by the activity and growth of LAB. The addition of cilembu starch $3 \%$ produced the highest value of $L A B, 5.400 \log 10$ cfu. $\mathrm{ml}^{-1}$. The more number of $\angle A B$, the more acid is produced, so that the $\mathrm{pH}$ decreased.

Lactic acid bacteria are capable of producing pectinolytic and cellulolytic enzymes that can destroy the cell walls of the starch [18], resulting differences in concentration. Lactic acid bacteria have a high concentration after releasing the enzyme and starch had low concentrations after their cell wall destroyed. This causes the LAB could hydrolyze starch and lactose. Lactose hydrolyzed into its constituent compounds, galactose and glucose, whereas raffinose and stachyose (sugar derived from starch) is hydrolyzed by the enzyme $\alpha$-galactosidase into galactose, glucose and fructose [2]. The metabolism of sugar in the form of organic acids, such as lactic acid, citric acid, and others which resulted decrease in $\mathrm{pH}$. The addition of prebiotics is able to accelerate the process of acid formation, thus lowering the $\mathrm{pH}$ due to high activity and growth of LAB. One study suggested that fermented soy milk ranging from 4, 8, 12, 16 and 20 hours will be decreased $\mathrm{pH}$. From $\mathrm{pH}$ control at 6.7 to 4.6 at the end of fermentation, comparable to total lactic acid produced, from 0 , $11 \%$ to $0.31 \%$ [3].

Analysis of variance showed that different frozen storage times on synbiotic yoghurt ice cream provide no significant difference $(P \geq 0.05)$ of the $\mathrm{pH}$ values. In freezing conditions, the metabolism occur in very slow cycle, thus the change in $\mathrm{pH}$ that appeared was very small, only 0.003 to 0.025 . Change of $\mathrm{pH}$ is influenced by the activity of LAB. In this research, decreased of total $L A B$ occurs in small quantities, because of the addition of starch which act as a protective material for $L A B$. Changes in $\mathrm{pH}$ value were very small and the treatment had no effect declared, but the longer of frozen storage, the $\mathrm{pH}$ value increased. This corresponds to a decrease in total $L A B$ during frozen storage, thus reshuffle lactose by $L A B$ into lactic acid also decreases and causes increases of $\mathrm{pH}$ value.

A study shows that the longer of the frozen storage of probiotic ice, then the lactic acid levels tend to decrease. The results showed ice cream with probiotic starter Lactobacillus casei and Bifidobacteriumbifidium (1: 1), the storage time of 10 days resulted in an average of $0.24 \%$ lactic acid, 20 days $0.23 \%$, and 30 days $0.21 \%$ [14]. Decreased levels of lactic acid will increase the $\mathrm{pH}$ value. Results of other studies indicated that goat's milk yoghurt was kept frozen for 2, 4, 6 days had an average $\mathrm{pH}$ value of 5.51 (control), 5.94; 5.41; 5.61, respectively [19]. Changes in pH value leads to changes in the concentration of $\mathrm{H}^{+}$ ions, so these changes will affect the value of the coefficient of absorption of milk due to the addition of $\mathrm{H}^{+}$ions that causes the density differences [20].

\section{Exopolysaccharide (EPS)}

Statistical analysis showed that the addition of Cilembu sweet potato starch with different concentration on synbiotic yoghurt ice cream provide higly significant difference $(P \leq 0.01)$ of the EPS values. The highest EPS produced by the addition of starch $3 \%\left(P_{3}\right)$, which is 0.200 g.L $L^{-1}$. Exopolysaccharide production is generally related to the total $L A B$, because the EPS is produced by $\angle A B$. The highest value of total $L A B$ is indicated by $P_{3}\left(5.400 \log 10\right.$ cfu. $\left.\mathrm{mL}^{-1}\right)$, thus $P_{3}$ showed the highest EPS results.

Bacterial growth is divided into four phases, the first phase is lag (phase adaptation), the current phase of the bacteria have to adjust with the environment. Second, a log phase as bacterial growth phase. Third, the stationary phase where growth rate and mortality of bacteria are in a balanced state. Fourth, the death phase when the death rate has exceeded the growth rate of bacteria. EPS production will reach a maximum point when it reaches the stationary phase [21].

One study showed that the average EPS from the fermentation process of yoghurt during 3 days have the highest value than fermentation 1 and 2 days, of which the value was $35.15 \mathrm{mg} \cdot \mathrm{L}^{-1}$ (1 day), $37.25 \mathrm{mg} \cdot \mathrm{L}^{-1}$ (2 days) and $56.05 \mathrm{mg}^{-1} \mathrm{~L}^{-1}$ (3 days) [22]. Exopolysaccharide degraded because of the low activity of EPS enzymes in the next stage. The fermentation process lasts for only 24 hours in this study, thus the production of EPS has not reached the maximum value.

Exopolysaccharide produced in this study was crude EPS, because it is obtained by calculating the weight after drying. Crude EPS at 0 hour was

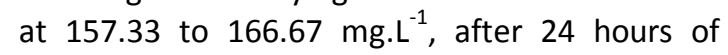
fermentation, increased to 579.00 to 2469.67 mg. L $^{-1}[23]$. 
Production of EPS can be affected by sources ofcarbon and nitrogen, physicochemical of LAB growth, such as temperature, $\mathrm{pH}$, the presence of oxygen levels [24]. Minerals are needed for the synthesis of EPS. One study stated that the production of EPS achieve the best result (475.6 $\mathrm{mg} . \mathrm{L}^{-1}$ ) with the addition of $0.5 \%$ sodium acetate, while the addition of magnesium sulphate lead to decreased production of EPS, the addition of potassium phosphate and citrate triamonium best produce EPS production at concentrations of $0.2 \%$ [25]. Minerals in Cilembu sweet potato such as calcium $\pm 30 \mathrm{mg} .100 \mathrm{~g}^{-1}$ of sweet potatoes. Mineral is a component that is insoluble in water, thus the mineral of Cilembu sweet potato remain in produced starch even after undergoing a process of soaking. Microorganisms only takes few minerals, the exceeded amount of minerals can inhibit the growth of LAB [25]. The addition of starch $1-3 \%$ increase in total LAB and EPS, while $4-6 \%$ start resulted in a decrease in the number of LAB and EPS. It can be caused by too much mineral content on the addition of these concentrations.

Analysis of variance showed that different frozen storage times on synbiotic yogHurt ice cream provide higly significant difference $(P \leq 0.01)$ of the EPS values. Storage time of 6 weeks resulted in the highest EPS value, 0.327 g. $\mathrm{L}^{-1}$. EPS production increased from $0.205 \mathrm{~g} . \mathrm{L}^{-1}(2$

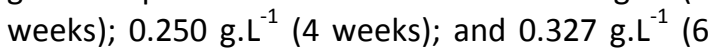
weeks). Formation of EPS is part of a defense of bacteria in bad conditions [26]. Frozen storage causes dormant on bacteria and viability of bacteria can be decreased [27]. The amount of EPS produced and resistance during freezing did not find any correlation [28], and freeze-dried for storage of cells [29]. Exopolysaccharide does not protect the bacteria from low temperatures. After 162 days of storage at temperature $-40^{\circ} \mathrm{C}$, melting at $4^{\circ} \mathrm{C}$ and freezing again at $-40^{\circ} \mathrm{C}$, viability of bacterial cell decreased 1-4\% [28]. From the three statements, we can drawn a conclusion that the frozen storage causing bacteria through a phase of dormancy, so the bacterial activity is inhibited and do not affect the production of EPS.

Storage temperature at $5^{\circ} \mathrm{C}$ can cause browning occurs due to the Maillard reaction, which can not be seen clearly using the naked eye [30]. The Maillard reaction is a reaction between carbohydrates, in particular reducing sugar and a primary amine group. Maillard reaction is a nonenzymatic browning reaction [10]. The interaction between protein and carbohydrates can cause discoloration even if it stored at a temperature of $5^{\circ} \mathrm{C}$, thus the frozen storage of allow interactions between carbohydrates, although in a slow cycle. Carbohydrates can be derived from the rest of the lactose which has not fermented, oligosaccharides (raffinose and stahyose) of Cilembu sweet potato starch, glucose is added when making the ice cream. The interaction between sugars can form transgalactosidase and increase the production of EPS.

\section{Viscosity}

Analysis of variance showed that the addition of Cilembu sweet potato starch with different concentration on synbiotic yoghurt ice cream provide higly significant difference $(P \leq 0.01)$ of the viscosity values. The addition of $6 \%$ starch produce the highest viscosity value, i.e. 103.180 $P$. Value of viscosity was higher with more starch is added, the highest concentration of starch that been used in this research was 6\%; that's why the viscosity values in this level was high than the other.

Starch consists of $18 \%$ amylose and $82 \%$ amylopectin [10]. Amylopectin of starch has a higher water absorption ability [9], thus increase the viscosity. The increase in viscosity occurs due to gelatinization of Cilembu sweet potato due to the heating process. The starch granules are able to absorb water. The process of water absorption occurs when the kinetic energy of water molecules is stronger than the power of attraction between molecules of starch in the water. The process of water absorption resulting in swelling. The starch granules that already swollen can not be returned as the initial size, thus resulting in increased viscosity [10].

Other constituents of ice cream also contributed to the increase in viscosity, such as a stabilizer. Carboxy Methyl Cellulose (CMC) used in the manufacture of ice cream can increase the viscosity $(2.13 \%)$. It is because $\mathrm{CMC}$ dispersed in the liquid phase capable of binding large amounts of water and forms a gel that blocks the water framework to freedom of movement, so that the state the solution becomes more stable due to increased viscosity [31].

ANOVA results showed that different of frozen storage times on synbiotic yoghurt ice cream providehigly significant difference $(P \leq 0.01)$ of the viscosity values. The ice crystals are formed when a product is frozen below the freezing point of water. Homogenic nucleation is a combination between the water molecules that can cause the formation of ice crystals [32]. The 
longer of frozen storage time, the more amount of ice crystals produced, so the buildup of ice crystals will lead to increase in viscosity.

Ice cream has an unstable crystal and during frozen storage, the crystal will change either in the number, size or shape, so it is called recrystallization. Recrystallization can occur naturally at a constant temperature, but most commonly affected by temperature fluctuations. Recrystallization can occur at temperature $-5^{\circ} \mathrm{C}$. One study showed that ice crystals can grow in size at a temperature of $-5^{\circ} \mathrm{C}$ and kept for 5 days, from $45 \mu \mathrm{m}$ to $110 \mu \mathrm{m}$, the largest ice crystals found even reach $200 \mu \mathrm{m}$ [33]. The water is converted into ice could increase the volume until $9 \%$, the increased volume due to lower temperature. Food products that contain a lot of water, there will be the same, but the water content, the annealing temperature and the presence of space between cells greatly affect the volume changes [34].

Increased viscosity of yoghurt can be affected by the bacterial strain producing EPS [35]. Some types of LAB were able to produce EPS are Lactobacillus acidophillus, $L$. casei, and $L$. plantarum [23]. Exopolysaccharide able to act as a thickener to increase the viscosity. The results showed when the EPS production of $0.200 \mathrm{~g} . \mathrm{L}^{-1}$ value of the viscosity of the ice cream is $40.257 \mathrm{P}$. Exopolysaccharide achieving maximum production at 6 weeks of storage, $0.327 \mathrm{~g} . \mathrm{L}^{-1}$. At the same time the value of the viscosity of the ice cream also reaches the maximum value is $114.928 \mathrm{P}$.

\section{Melting Rate}

The addition of different concentration Cilembu sweet potato starch on synbiotic yoghurt ice cream showed a higly significant difference $(P \leq 0.01)$ of the melting rate values. The melting rate is affected by the total solids contained in the ice cream [36]. Cilembu sweet potato starch is a source of solids [9], the more amount of starch added, the lower speed of melting rate. The melting rate of synbiotic ice cream without the addition of cilembu starch was 26.150 minutes. $50 \mathrm{~g}^{-1}$ and with the addition of Cilembu starch $6 \%$ was 45.050 minutes. $50 \mathrm{~g}^{-1}$ as the highest value. It happened because of the increased solids led to the freezing point of ice cream down, water holding capacity of ice cream is getting stronger and the movement of free water is reduced, thus much water is trapped. Increasing the number of free water trapped will produce ice cream that slowly melts [37]. One study showed that a combination of ice cream with soy extract $40 \%$ and $15 \%$ cucumber pulp produces melting rate of $25.89 \mathrm{~min}$ [38].

Melting rate of ice cream can be affected by the constituents of ice cream. Ice cream with a high fat content will not be easy to melt [39]. Stabilizers also give effect to the melting rate. Stabilizer dispersed in the liquid phase bind large amounts of water and forms a gel framework which prevents water molecules move freely and formed membranes of ice cream that will protect components from the effects of temperature [31].

Melting rate related to the viscosity of the ice cream. High viscosity will produce ice cream with a low melting rate, consequently generated overrun value can be decreased. Observation on the melting rate of ice cream, indicates that the ice cream with low overrun value has a melting time which tended to last longer. One study showed that an ice cream with combination of the skim milk $0 \%$ and $10 \%$ sweet potato steamed produce a maximum melting speed that is 8.58 minutes, while the value of overrun was low, $22.2 \%$ [40]. Melting rate of ice cream in this study was of 25-45 minutes. $50 \mathrm{~g}^{-1}$. Actually, melting rate of ice cream is about 10-15 minutes [36]. It shows that the ice cream produced in this study is good because it has a longer melting time.

Different frozen storage times on synbiotic yoghurt ice cream provide high significant difference $(P \leq 0.01)$ of the melting rate values. The longer of frozen storage time, the more amount of ice crystals produced. That ice crystal can be changes in the number, shape and size into more numerous and larger during frozen storage causes increased viscosity of the ice cream. Along with increased viscosity, melting rate of ice cream decreases. The results showed that synbiotic yoghurt ice cream without treatments, viscosity value was lower by $40.257 \mathrm{P}$ and the value of melting rate was high of 35.523 minutes. $50 \mathrm{~g}^{-1}$. While synbiotic yoghurt ice cream stored for six weeks, the value of the viscosity is high, amounting to $114.928 \mathrm{P}$ and the melting rate low at 48.828 minutes. $50 \mathrm{~g}^{-1}$.

Other studies mention that the ice cream with the addition of $L$. casei and Bifidobacterium bifidum (1: 1) were kept frozen for 10, 20, 30 days had value of melting rate 6.85 minutes, 8.49 minutes, 10.30 minutes, respectively [14]. The melting rate of yoghurt ice cream stored for 1 month is 4.55 minutes. $100 \mathrm{~g}^{-1}$, and after saving three months to 4.61 minutes. $100 \mathrm{~g}^{-1}$. Measurements were performed in the temperature of $24^{\circ} \mathrm{C}$ with a maximum score of 5 [41]. 
Melting rate of ice cream can be affected by many factors, including the amount of trapped air, ice crystals and fat globules tissue are formed during freezing [37]. The decrease of temperature of frozen storage, resulting the water will freeze back through the nucleation process (determining the cell nucleus), so the size of the ice crystals will increase to $\geq 100 \mu m$ [42]. Its shape becomes rough, either on the surface or the interior of ice cream.

Glucose can withstand freezing so that ice cream is not easy to melt, especially after storage at low temperature $\left(-18^{\circ} \mathrm{C}\right)$ [43]. Synbiotic yoghurt ice cream is made by adding sugar as much as $375 \mathrm{~g} . \mathrm{L}^{-1}$ milk. The addition of high sugar was assumed to play a role in the decrease of melting rate. Use of sweeteners such as sugar as much as $25 \%$ may increase the viscosity because it is able to lower the water activity [44], thus slowing the melting rate ice cream.

\section{Overrun}

Analysis of variance showed that the addition of Cilembu sweet potato starch with different concentration on synbiotic yoghurt ice cream provide highly significant difference $(P \leq 0.01)$ of the overrun values. Value of overrun was lower with more starch is added. Amylopectin on starch is $82 \%$ with regard to the group branched chain $\alpha 1,6$ [10]. Thus, it is difficult to penetrate by air when the foaming and freezing process, so the value of overrun decreased. The highest concentration of starch that been used in this research was $6 \%$, that's why the overrun values in this level was low than the other, which amounted to $10.257 \%$.

Starch molecules have a very large number of hydroxyl groups, so it had the higher ability to absorb water and affect the increased of viscosity [10]. Decreasedof overrun occurred along with an increase in viscosity due to increased of adding Cilembu sweet potato starch. Solids are too high in ICM, can increase viscosity, thereby inhibiting the development of ICM and lowered overrun [31]. One study showed that a combination of skimmed milk $0 \%$ and $10 \%$ sweet potato steamed showed the lowest value of overrun, $22.22 \%$, while the combination of $10 \%$ skim milk and sweet potato steamed $0 \%$ showed the highest value of overrun, $63.33 \%$ [40].

\section{Microstructures}

Microstructure of synbiotic yogurt ice cream can be seen in Figure 1. The image of ice cream was taken with a magnification of $1000 x$ for the visible presence of EPS. Figure $2 \mathrm{~d}$ looks has more EPS than other images, according to the results of EPS production of 6 weeks resulted in the highest value, i.e. $0.327 \mathrm{~g} \cdot \mathrm{L}^{-1}$.

Figure 1d sample had a high density compared to other images. Figure $1 \mathrm{a}$ and $1 \mathrm{~b}$ were still seen the empty cavities, while Figure $1 \mathrm{c}$ empty cavity began to decrease. Density formed in Figure 1d because the longer stored at freezing temperatures, thus the ice crystals in ice cream will be found more.
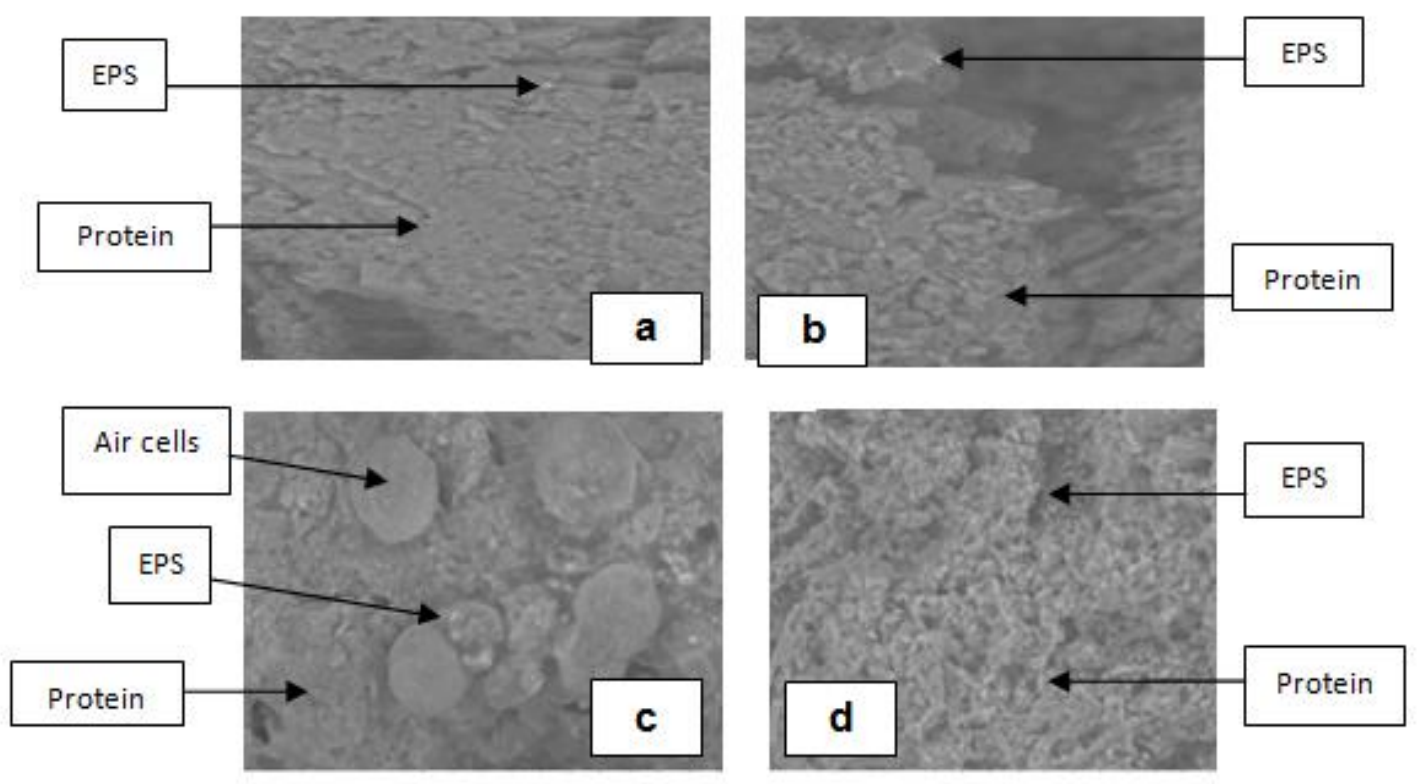

Figure 1. Microstructure of Synbiotic Yoghurt Ice Cream with Various Storage Time a. without storage, b. 2 weeks storage, c. 4 weeks storage, d. 6 weeks storage 
During frozen storage, the ice cream will have two events, i.e. propagation and recrystallization. Propagation is the process when the volume of ice in the ice cream increases, low temperatures cause the size of the ice crystals become larger with frozen water molecules around it. Recrystallization occurs when small ice crystals melt, and then freeze again in a larger size [45]. The ice crystals which formed were more numerous with sizes getting bigger and rough texture, thus increasing the viscosity of ice cream. Viscosity in the sixth week had the highest value, $114.928 \mathrm{P}$. Viscosity of the ice cream will be increased because of two things, the low temperature and the viscosity of the suspension of solid particles increases as the volume fraction of solid [41].

The freezing process does not affect the metabolism of proteolysis. Proteolysis metabolism is still running [46]. Freezing causes of nonprotein nitrogen (NPN) increased, possibly due to damage cause by ice crystals in the case in matrix and cell bacteria liberate proteolytic enzymes into the media [47]. The formation of ice crystals during freezing cause the dehydration of the protein thus encourages the breakdown of the protein structure. This causes tiny fat droplets interact and form larger granules. Protein becomes denser or interact to form a disulfide bridge around the newly formed fat granules. After the liquefaction process, the protein can not fully bind the water back [48].

\section{CONCLUSION}

The addition of 1-6\% Cilembu sweet potato starch was able to increase viscosity, lowering the melting rate and overrun. The addition of starch 1-3\% increased the total LAB, EPS and lowering the $\mathrm{pH}$. The addition of $4-6 \%$ starch lowers total LAB, EPS and increase $\mathrm{pH}$. Storage at 2, 4 and 6 weeks increased the $\mathrm{pH}$, EPS, viscosity, melting rate and lowers of total LAB.

We recommend increasing the storage time to know the maximum time limit of storage for synbiotic yoghurt ice cream to maintain its quality. We also recommended advancing testing of EPS to prove the truth of produced EPS, because synbiotic yoghurt ice cream has many constituent components.

\section{ACKNOWLEDGEMENT}

This work was partly supported by the Directorate General of Higher Education (DIKTI) scholarship (2014-2015).

\section{REFERENCES}

[1] Harjiyanti, M.D., Y.B. Pramono, S. Mulyani. 2013. Total asam, viskositas dan kesukaan pada yoghurt drink dengan sari buah mangga (Mangifera indica) sebagai perisa alami. Jurnal Aplikasi Teknologi Pangan. 2(2). 104-107.

[2] LeBlanc, J.G., M.S. Garro, A. Silvestroni, C. Connes, J.C. Piard, F. Sesma, S. de Giori. 2004. Reduction of $\alpha$-Galacto oligosaccharides in soya milk by Lactobacillus fermentum CRL 722: In Vitro and In Vivo evaluation of fermented soya milk. J. Appl. Microbiol. 97. 876-881.

[3] Yusmarini, R. 2010. Aktivitas proteolitik bakteri asam laktat dalam fermentasi susu kedelai. J. Teknol. Industri Pangan. 111 (2). 129-134.

[4] Anggraeni, A.A. 2013. Aplikasi Inulin pada low-fat ice cream sebagai diversifikasi pangan prebiotik. Faculty of Engineering, State University of Yogyakarta. Yogyakarta.

[5] Sukardi, M. Hindun, N. Hidayat. 2014. Optimasi penurunan kandungan oligosakarida pada pembuatan tepung ubi jalar dengan cara fermentasi. Department of Agriculture Industry Technology, Faculty of Agriculture Technology, University of Brawijaya. Malang.

[6] Mikasari, W., L. Ivanti. 2013. Sifat organoleptik dan kandungan nutrisi es krim ubi jalar varietas lokal Bengkulu. Centre pf Agriculture Technology Research. Bengkulu.

[7] Anonymous. 2008. Eksopolisakarida pada jamur tiram. http://www.searchenginepdf. com. Accessed on September $2^{\text {nd }} 2014$.

[8] Petry, S., S. Furlan, M.J. Crepeau, J. Cerning, M. Desmazeaud. 2000. Factors affecting exocellular polysaccharide production by Lactobacillus delbrueckii sub sp. Bulgaricus grown in a chemically defined medium. Appl. Environ. Microbiol. 66(8). 3427-3431.

[9] Hartati, N.S., T.K. Prana. 2003. Analisis kadar pati dan serat kasar tepung beberapa kultivar Talas (Colocasiaesculenta L. Shott) Jurnal Natur Indonesia. 6(1). 29-33.

[10] Winarno, F.G. 2002. Kimia pangan dan gizi. PT. Gramedia Pustaka Utama. Jakarta.

[11] Degarmo, E.P., W.G. Sullivan, J.A. Bontadelli. 1993. Engineering Economy. McMilan. New York.

[12] Utami, R., M.A.M. Andriani, Z.A. Putri. 2010. Kinetika fermentasi yoghurt yang diperkaya ubi jalar (Ipomea batatas). Jurnal Caraka Tani. 25(1). 50-55. 
[13] Beal, C., F. Fonseca, G. Corrieu. 2000. Resistance to freezing and frozen storage of streptococcus thermophilus is related to membrane fatty acid composition. J. Dairy Sci. 84(11). 2347-2356.

[14] Mulyani, S., A.M. Legowo, A.A. Mahanani. 2008. Viabilitas bakteri asam laktat, keasaman dan waktu pelelehan es krim probiotik menggunakan starter Lactobacillus casei dan Bifidobacterium bifidum. J. Indon. Trop. Anim. Agric. 33(2). 120-125.

[15] Hekmat, S., J. Mc Mahon. 1992. Survival of Lactobacillus acidophilus and Bifidobacterium in ice cream for use as a probiotic food. J. Dairy Sci. 75. 1415-1422.

[16] Gibson, G.R., R. Fuller. 1999. Functional food: the consumer, the health and the evidence. Cambrige.

[17] Davidson, R.H., S.E. Duncan, C.R. Hackney. 1999. Probiotic curture in survival and implicationt in fermented frozen yogurt characteristics. J. Dairy Sci. 83. 666-673.

[18] Anggraeni, Y.P., S.S. Yuwono. 2014. Pengaruh fermentasi alami pada chips ubi jalar (Ipomoea batatas) terhadap sifat fisik tepung ubi jalar terfermentasi. Jurnal Pangan dan Agroindustri. 2(2). 59-69.

[19] Cahyanti, A.N. 2011. Viabilitas probiotik Lactobacillus casei pada yogurt susu kambing selama penyimpanan beku. Jurnal Teknologi Pertanian. 12(3). 176-180.

[20] Astomo, T.Y. 2009. Pengaruh lama waktu penyimpanan terhadap $\mathrm{pH}$ dan koefisien serap sinar gamma pada susu. Diponegoro University. Semarang.

[21] Yuliana, N. 2008. Kinetika Pertumbuhan bakteri asam laktat isolat T5 yang berasal dari tempoyak. Jurnal Teknologi Industri dan Hasil Pertanian. 13(2). 108-116.

[22] Oktavia, H. 2015. Evaluasi sifat fisikokimia dan produksi eksopolisakarida kultur tunggal dan kultur campuran pada set yogurt. Master Thesis. Faculty of Animal Husbandry, University of Brawijaya. Malang.

[23] Zubaidah, Y., Y. Liasari, E. Saparianti. 2008. Produksi eksopolisakarida oleh Lactobacillus plantarum B2 pada produk probiotik berbasis buah murbei. Jurnal Teknologi Pertanian. 9(1). 59-68.

[24] Halim, C.N., E. Zubaidah. 2013. Studi kemampuan probiotik isolat bakteri asam laktat penghasil eksopolisakarida tinggi asal sawi asin (Brassica juncea). Jurnal Pangan dan Agroindustri. 1(1). 129-137.
[25] Malaka, R., Metusalach, E. Abustam. 2014. Pengaruh jenis mineral terhadap produksi eksopolisakarida dan karakteristik pertumbuhan Lactobacillus bulgaricus Strain Ropy dalam media susu. Faculty of Animal Husbandry, Hasanuddin University. Makassar.

[26] Ruas-Madiedo, P., J. Hugenholtz, P. Zoon. 2002. An overview of the functionality of exopolysaccharides produced by lactic acid bacteria. Int. Dairy J. 12. 163-171.

[27] Kumalaningsih, S., Wignyanto, V.R. Permatasari, A. Triyono. 2015. Pengaruh jenis mikroorganisme dan $\mathrm{pH}$ terhadap kualitas minuman probiotik dari ampas tahu. Faculty of Agriculture Technology. University of Brawijaya. Malang.

[28] Looijesteijn, P.J., J.L. Trapet, E. de Vries, T. Abee, J. Hugenholtz. 2001. Physiological function of exopolysaccharides produced by Lactococcus lactis. Int. J.Food Microbiol. 64. 71-80.

[29] Carvalho, A.S., J. Silva, P. Ho, P. Teixeira, F. X. Malcata, P. Gibbs. 2003. Effect of different sugars added to the growth and drying medium upon thermotolerance and survival during storage of freeze-dried Lactobacillus delbrueckii ssp. bulgaricus. Biotechnol. Progr. 20. 248-254.

[30] Al-Saadi, J.M.S., H.C. Deeth. 2008. Crosslinking of proteins and other changes in UHT milk during storage at different temperatures. Aust. J. Dairy Technol. 63(3). 93-99.

[31] Widiantoko, R.K., Yunianta. 2014. Pembuatan es krim tempe-jahe (kajian proporsi bahan dan penstabil terhadap sifat fisik, kimia dan organoleptik). Jurnal Pangan dan Agroindustri. 2(1). 54-66.

[32] Fellows, P.J. 2000. Food processing technology principals and practice $2^{\text {nd }} E d$. CRC Press. New York.

[33] Donhowe, D.P., R.W. Hartel. 1996. Recrystallization of ice in ice cream during controlled accelerated storage. Int. Dairy J. 6. 1191-1208.

[34] Kalichevsky, M.T., D. Knorr, P.J. Lillford. 1995. Potential food applications of high pressure effects on ice water transitions. Trends Food Scie. Tech. 6. 253-258.

[35] Gursoy, A., F. Durlu-Ozkaya, F. Yildiz, B. Aslim. 2010. Set type yoghurt production by exopolysaccharide producing turkish origin domestic strains of Streptococcus thermophilus (W22) and Lactobacillus delbrueckii 
ssp. bulgaricus (B3). Kafkas Univ. Vet. Fak. Derg. 16. 81-86.

[36] Achmad, F., Nurwantoro, S. Mulyani. 2012. Daya kembang, total padatan, waktu pelelehan dan kesukaan es krim fermentasi menggunakan starter Saccharomyces cereviceae. Anim. Agr. J. 1(2). 65-76.

[37] Muse, M.R., R.W. Hartel. 2004. Ice cream structural element that affect melting rate and hardness. J. Dairy Sci. 87(1). 1-10.

[38] Oksilia, M.I., Syafutri, E. Lidiasari. 2012. Karakteristik es krim hasil modifikasi dengan formulasi bubur timun suri (Cucumis melo L.) dan sari kedelai. Jurnal Teknologi dan Industri Pangan. 23(1). 17-22.

[39] Buckle, K.A., R.A. Edward, G.H. Fleet, M. Wooton. 1987. Ilmu pangan. University of Indonesia Press. Jakarta.

[40] Elisabeth, D.A.A., M.A. Widyaningsih, I.K. Kariada. 2007. Pemanfaatan umbi ubi jalar sebagai bahan baku pembuatan es krim. Jurnal Balai Pengkajian Teknologi Pertanian (BPTP). Bali.

[41] Mangsi, A.S., A.H. Soomro, M.H. Baloch, M. Khaskheli, A.H. Nizamani and G.B. Khaskheli. 2011. Production and evaluation of yoghurt ice cream. Pakistan J. Nutr. 10(10). 955-958.

[42] Clarke, C. 2003. The physics of ice cream. PER. 38(3). 248-253.

[43] Abdullah, M., S. Rehman, H. Zubair, H.M. Saeed, S. Kousar, M. Shahid. 2003. Effect of skim milk in soymilk blend on the quality of ice cream. Pakistan J. Nutr. 2(5). 305-311.

[44] Gianti, I., H. Evanuarini. 2011. Pengaruh penambahan gula dan lama penyimpanan terhadap kualitas fisik susu fermentasi. Jurnal Ilmu dan Teknologi Hasil Ternak. 6(1). 28-33.

[45] Buyck, J.R. 2010. Effect of storage temperature on ice cream quality. Master Thesis. South Dakota State University. Brookings.

[46] Alvarenga, N., J. Canada, I. Sousa. 2011. Effect of freezing on the rheological, chemical and colour properties of serpa cheese. J. Dairy Res. 78. 80-87.

[47] Graiver, N.G., N.E. Zaritzkydan, A.N. Califano. 2004. Viscoelastic behavior of refrigerated frozen low-moisture mozzarella cheese. J. Food Sci. 69(3). 123-128.

[48] Diefes, H.A., S.S.H. Rizvidan, J.A. Bartsh. 1993. Rheological behaviour of frozen and thawed low-moisture part skim, mozzarella cheese. J. Food Sci. 58. 764-769. 